\title{
The application of cooperative script method in teaching reading of narrative text at the first semester students of Universitas PGRI Madiun
}

\author{
Brigitta Septarini Rahmasari \\ Universitas PGRI Madiun, Jl. Setibudi No. 85 Madiun, Indonesia \\ e-mail: brigitta@unipma.ac.id
}

\begin{abstract}
Abstrak
Penelitian ini bertujuan untuk mendeskripsikan proses, kelebihan dan kekurangan dari implementasi metode Script Koperasi dalam pengajaran membaca pada siswa semester I Universitas PGRI Madiun. Jenis penelitian yang digunakan adalah penelitian deskriptif kualitatif. Metode skrip kooperatif dapat membuat siswa menikmati kegiatan belajar. Metode ini dapat memotivasi siswa untuk lebih baik dalam membaca kegiatan terutama memahami materi. Metode ini juga bisa membantu siswa untuk lebih kreatif dalam menyusun ringkasan dengan menggunakan kata-kata mereka sendiri. Mereka juga bisa memahami materi dengan baik. Selain itu, hal itu membuat siswa lebih fokus pada tugas mereka. Selain itu, dapat membantu siswa untuk lebih komunikatif dengan teman mereka untuk menceritakan pendapat mereka. Selanjutnya, metode ini membuat siswa berani menceritakan pendapat mereka di depan kelas. Yang terakhir, metode ini bisa membuat situasi kelas lebih hidup karena masing-masing kelompok memusatkan perhatian pada masalah mereka. Metode skrip koperasi juga memiliki kelemahan dalam pengajaran membaca. Pertama, kelas ramai karena banyak siswa yang ribut saat menceritakan pendapat mereka di kelompok mereka. Kedua, dosen kurang memperhatikan setiap kelompok karena dia hanya fokus pada beberapa kelompok yang nampaknya sangat serius dalam melakukan tugasnya.
\end{abstract}

Kata kunci: Membaca; Teks Narasi; Metode Cooperative Script

\begin{abstract}
This research is aimed at describing the process, the advantages and disadvantages of the implementation of Cooperative Script method in teaching reading at the first semester students of Universitas PGRI Madiun. The type of research applied was a descriptive qualitative research. Cooperative script method can make students enjoy the learning activities. This method can motivate students to be better in reading activities especially understanding the materials. This method can also help students to be more creative in arranging summary using their own words. They also can comprehend the materials well. Moreover, it makes students more focus on their task. In addition, it can help students to be more communicative with their friends to tell their opinions. Furthermore, this method makes students courageous to tell their opinion in front of the class. The last, this method can make classroom situation more alive because each group focuses on their problem. The cooperative script method also has disadvantages in teaching reading. First, the classroom is crowded because many students are noisy when they tell their opinion in their group. Second, the lecturer gives less attention in every group because he just focuses on some groups that seem really serious about doing their tasks.
\end{abstract}

Keywords: Reading; Narrative Text; Cooperative Script Method 


\section{Introduction}

Indonesia is one of the countries in the world that uses English as International language. In Indonesia, English have been taught from elementary school until university. There are four English skills that are important to be learnt by students. They are Listening, Speaking, Reading, and Writing. Reading is one of the important skills in learning English. Urquhart and Weir (1998: 17) define, "Reading is the process of receiving and interpreting information encoded in language from via the medium of print." In this research, the researcher will focus on one type of text that is Narrative text. Anderson and Anderson (1997: 8) define, "Narrative is a piece of text, tells a story and, in doing so, entertains informs the reader or listener." It means that, narrative text is a text that tells story to amuse the readers.

Based on observation, there are many problems viewed from students' point of view and teachers' point of view. First, students cannot answer the questions of the text materials. Second, students cannot understand the text. Third, the vocabularies on the text are too difficult to be understood by the students. Fourth, they cannot summarize the text using their own words. Fifth, students are afraid to give ideas about the content of the text. The last, students are shy to tell the story in front of their friends.

Not only students, but also the teachers cause problems such as first, they less monitor activity of students. Second, they cannot give explanation about the materials clearly. Third, they do not master the materials. Fourth, they cannot make a good communication with their students.

Based on the problems above, the researcher uses Cooperative Script method in teaching reading of narrative text. O'Donnell and Danserau (in Lazarowitz and Miller, 1995: 129) states, "Cooperative Script is mechanism that guides the interaction of cooperating groups as they complete the designated task." Besides, Agus Suprijono (2012: 126) states that cooperative script method is a method of learning in which students work in pairs and take turns orally summarizing, part-the part of the material being studied.

The researcher assumes that this method has advantages such as first, this method can motivate students to be better in reading. Second, this method can help to develop students' creativity in arranging sentences using their own words. Third, it makes students more focus and responsible in their tasks. Fourth, it makes students more communicative. Fifth, it makes teachers and students have good communication. Sixth, this method makes students more courageous to tell their opinions. The last, this method can make classroom situation more alive.

In this research, the researcher mentions two problem statements. They are how is the application of cooperative script method in teaching reading of narrative text and what are the advantages and disadvantages of the application of cooperative script method in teaching reading of narrative text.

Besides, the researcher also mentions the purpose of the study of this research. They are to describe the application of cooperative script method in teaching reading of narrative text and to find the advantages and disadvantages of the application of cooperative script method in teaching reading of narrative text. 
Nunan (2003: 68) states, "Reading is a fluent process of reader combining information from a text and their own knowledge to build meaning." Besides, Urquhart and Weir (1998: 22) define, "Reading is the process of receiving and interpreting information encoded in language from via the medium of print." Moreover, according to Grabe and Stoller (2002: 09) "reading is the ability to draw meaning from the printed page and interpret this information appropriately". In addition, Vacca, Vacca, \& Gove (in Bambang Yudi Cahyono, 2011: 57) state, "Reading is a means of communicating information between the writer and the reader. The reader tries to understand ideas that the writer has put in print."

Based on theories above, it can be concluded that reading is the process of connecting the readers' background knowledge with the content of the text' to get the ideas and understand the information of the text. Also reading is a skill of comprehending the intentional meaning from texts.

Nunan (2003: 68) states, "Teaching reading usually has at least two aspects. First, it can refer to teaching learners who are learning to read for the first time. A second aspect of teaching reading refers to teaching learner already have reading skill in their first language. It means that to teach reading skill." It can be concluded that teaching reading is teaching students who are able to read in the beginning level and who have reading skills in advanced level. are:

According to Hammer (1998: 70), the principles behind of the teachings reading

- Reading is not a passive skill.

Reading is an incredibly active occupation such as understanding what the words mean, see the pictures the words are painting, understand the arguments, and work out if agree with them.

- Students need to engaged with what they are reading.

The student's job must be united with the reading text. The students who can do this job will get more benefit from it and vice versa.

- Students should be encouraged to respond to the content of a reading text, not just to the language.

It is important for the students to learn about reading texts for the way they use language. Conveying the meaning of reading text is important. The teacher should give the students a chance to give their respond about the message in their own way.

- Prediction is a major factor in reading.

In understanding of reading texts, the students must have good idea of the content before the actually read. The ideas of the students appear from their prediction.

- Match the task to the topic.

The teachers need to choose good reading task such as, the read kind of question, engaging useful puzzle etc. The most interesting text can be undermined by asking boring and inappropriate questions; the most commonplace passage can be made really exciting with imaginative and challenging tasks.

- Good teachers exploit reading texts to the full.

Good teacher must integrate the reading text into interesting class sequences and using the topic for discussion and further tasks. 
Based on statements above, it can be concluded that in teaching reading has principles such as reading is not a passive skill, Students need to engaged with what they are reading, students should be encouraged to respond to the content of a reading text, not just to the language, prediction is a major factor in reading, match the task to the topic, good teachers exploit reading texts to the full.

\section{Cooperative Script Method}

a. Definition

According to O'Donnell and Dansereau (in Lazarowitz and Miller, 1995: 129), "Cooperative Script is mechanism that guides the interaction of cooperating groups as they complete the designated task." Furthermore, Lailatun Nashiroh (2012: 4) state, "Cooperative script is a method in learning that makes students work in pair." Agus Suprijono (2013:126) also defines that Cooperative Script method is a method of learning in which students work in pairs and take turns orally summarizing, part-the part of the material being studied. According to Slavin (2009: 247), "Cooperative Script is a study method in which students work in pairs and take turns orally summarizing sections of material to be learned." Slavin (2006: 259) defines that many students find it helpful to get together with classmates to discuss material they have read or heard in class. While one student summarizes, the other listens and corrects any errors or omissions.

Based on experts above, it can be concluded that Cooperative Script is activity in teaching and learning process where the students work in group and discuss to make summary orally from the materials of the texts that they learn. After that, they must present it in front of the other students.

b. The Steps

1) The teacher asks the students to make a group. Each group consists of 4 until 5 students.

2) The teacher distributes the narrative text to each group.

3) Every group is asked by teacher to make a summary of the story in narrative text.

4) The teacher chooses the groups who will be the reader and listener.

5) The reader must read their summaries in front of the class.

6) The listener listen carefully what the reader read based on their summaries of the text and correct wrong sentences of the text.

7) Change the role, who before be speaker change be listener and who before be listener now be speaker.

8) The teacher helps the students to correct the summary until it becomes a good paragraph.

9) Closing.

\section{Research Method}

This research uses qualitative research. In this research, the researcher uses Qualitative method because this research is based on social phenomenon. It is supported by Yin (2011: 3). Yin defines that in qualitative research, the researcher study a real-world setting, discover how people cope and thrive in that setting-and capture the contextual richness of people's everyday lives. 
The researcher analyzes the data using three steps of technique for analyzing data namely; data reduction, data display, and drawing conclusion or verification.

1. Data Reduction

There are many data that have been collected, so the researcher needs to reduce the data to get the clearer image and to make it easier to be analyzed. The step of data reduction is making note on the general meeting of the teaching learning process that is done by the teacher and learners.

2. Data Display

Narratively, the researcher displays the data, because it is easier to understand what happened and to plan the next work based on the understanding things. After the data are displayed, the researcher tries to describe and discuss the finding of the researcher in the form of systematic classification.

3. Drawing Conclusion

The researcher draws conclusion about the process and activity of reading teaching-learning, and graphic organizer strategies which are applied by the teacher.

\section{Research Findings and Discussion}

\section{The Application of Cooperative Script Method}

Before the teacher does teaching and learning process, the teacher prepares what he need in teaching and learning process. The teacher prepares syllabus, lesson plan, and materials for the teaching and learning process. Syllabus and lesson plan can help the teacher to make teaching and learning process run effectively. In this case, the basic material for teaching learning process is narrative text and the teaching method used is cooperative script method.

In teaching and learning process, the teacher divides activities into three parts. They are Pre-activities, Whilst-activities and Post-activities. It is presented as follows:

a. Pre-activities

In this step, the teacher starts the teaching and learning process by greeting the students. After that, the teacher checks the students' attendance list. Then, he asks about the previous materials. After that, the teacher gives apperception to the students by giving some questions related to the materials. The last, the teacher mentions the purpose of the study.

b. Whilst-activities

In this step, the teacher uses cooperative script method in reading class. There are some procedures that must be done by the teacher about the application of cooperative script method at the tenth grade students in senior high school in whilst activity. First, the teacher gives explanation about narrative text to the students. Second, the teacher asks to students about information such as characters, generic structure, and language features of narrative text based on explanation from the teacher. Third, the teacher explains about the procedures of cooperative script method for the students. Fourth, the teacher asks the students to make a group. Each group consists of 4 until 5 students. Fifth, the teacher distributes the narrative text to each group. Sixth, every group is asked by teacher to make a summary of the story in narrative text. The teacher gives the students 30 minutes to make a summary.

Then, the teacher chooses the groups who will be the reader and listener. Here, the reader must read their summaries in front of the class. After that, the listener listen

The application of cooperative SCRIPT method in teaching ... (Brigitta Septarini Rahmasari) 
carefully what the reader read based on their summaries of the text and correct wrong sentences of the text. After that, the teacher helps the group to correct the summary until it becomes a good paragraph. For this activity, the students need 40 minutes to read and correct the summary.

\section{c. Post-activities}

In this step, before the teacher closes the learning process, the teacher asks students' difficulties from the materials and makes the conclusion based on the materials taught. In the last, the teacher closes the learning process.

\section{The Advantages and Disadvantages of Cooperative Script Method}

After analysing the data in this research, the advantages of the application cooperative script method in teaching reading of narrative text are: (1) Cooperative script method can make students enjoy the learning activities, (2) this method can motivate students to improve their ability in reading activities especially understanding the materials that they learn, (3) it can help students to be more creative because they can use their own words to arranged the summary based on the text that they have been read previously and comprehend the materials well. In addition, this method makes students more focus on their task, (4) this method can help students be more communicative with their friends to tell their opinions and this method makes students active to tell their opinion in front of the class, And (5) this method can make classroom situation more alive because each group more focuses on their problem from the text.

Besides, after analysing the data in this research, the disadvantages of the application cooperative script method in teaching reading of narrative text are: (1) The classroom is crowded because many students are noisy when they tell their opinion in their group and (2) the teacher gives less attention to the students in every group. It is explained as follows:

\section{Cooperative script method can make students enjoy the learning activities.}

Based on the teacher interview, it shows that it can make the students enjoy in teaching and learning process. The teacher states that this method can make students enjoy and happy in teaching and learning process. It means that, the method that uses in teaching reading narrative text can make the students more enjoy and happy in the teaching and learning process.

Based on the student interview, it shows that it makes students enjoy when they learn about narrative text. Student states that they feel enjoy when they learn together with their friends. It means that students feel enjoy when they learn with their group in the learning process.

Based on observation, the researcher can conclude that all of students enjoy the class to learn about reading narrative text. It can be seen when the students are active to answer the teacher's question and pay attention to the teacher's explanation. It also can be seen in the researcher's note that when the students learn, they look fun and happy to follow the lesson. When the teacher explains the materials, the students pay attention to teacher. This method can motivate students to improve their ability in reading activities especially understanding the materials that they learn.

Based on the teacher's interview, it shows that it can make students understand reading text. It can make them improve their reading ability. The teacher states that this method can help students to be better and understand the material to improve their ability 
in reading activity. It means that, the method that uses in teaching reading narrative text can motivate students to improve their ability in the class. (See Appendix 2).

Based on the students' interview, it shows that it can make the students understand the text well. The student states that they can know and understand in the learning process easily. It means that, this method can help student to comprehend the material.

Based on observation, the researcher can see that all of students understand the materials. It can be seen when the students can answer all question when the teacher ask them related with the materials. They can also understand the material clearly. When they can understand the material, they also can improve their ability. It also can be seen from students' score that the students can improve their ability. Based on students' score, it can be seen that the students' score improve before and after using this method. Cooperative script method can help students be more creative because they can use their own words to arrange the summary based on the text that they have been read previously. This method makes students focus on their task.

Based on interview to the teacher, the teacher has opinion that this method has advantages that this method can help the students to be more creative to create their own words. The teacher states that this method has strengths that it can help the students more creative when they make the summary by using their own words. It means that this method can make students more creative to use their own word based on their knowledge of the text. Based on the students' interview, the students have opinion that this method make student focus on their task. The student states that it can make them focus on the assessment from the teacher. It means that this method can help students focus on their task given by teacher.

Based on observation, the researcher can see that in teaching and learning activity using this method, the students pay attention when the teacher gives the task for them. They also focus on answering the task from the teacher by work together to make the summary of the text by using their own words. The example can be seen as follows:

\section{SNOW WHITE}

Once upon a time there lived a little girl named Snow White. She lived with her Aunt and Uncle because her parents were dead.

One day she heard her Uncle and Aunt talking about leaving Snow White in the castle because the both wanted to go to America and they didn't have enough money to take Snow White.

Snow White did not want her Uncle and Aunt to do this so she decided it would be best if she ran away. The next morning she ran away from home when her Aunt and Uncle were having breakfast. She ran away into the woods.

She was very tired and hungry.

Then she saw this little cottage. She knocked but no one answered so she went inside and fell asleep.

Meanwhile, the seven dwarfs were coming home from work. They went inside. There they found Snow White woke up. She saw the dwarfs, the dwarfs said, what is your name? Snow White said, "My name is Snow White." 
Doc said, "If you wish you may live here with us." Snow White said, "Oh could (I)? Thank you. Then Snow White told the dwarfs the whole story and Snow White and the seven dwarfs lived happily ever after.

Then, the students make the summary using their own words. It can be seen below:

Snow white lived with her aunt and uncle because her parents were died. Snow white went to leave her house because her aunt and uncle will go to America and leave snow white alone in the castle. After that, snow white ran away into the woods. There she met with seven dwarfs. She lives with seven dwarfs and lived happily.

It can be seen that the students can use their own words in making the summary based on the text that they have been read previously. It means that they are creative when using their own words.

Cooperative script method can help students be more communicative with their friends to tell their opinions and this method makes students active to tell their opinion in front of the class.

Based on teacher's interview, it shows that this method have advantages to make students more courageous and communicative to tell their opinion. The teacher states that the students courageous to tell their opinion in their groups. It means that, this method can help students to be more courageous to tell their opinion to others in one group. Based on student's interview, the student states that they are more courageous to tell their opinion especially in front of the class. So it can make them have a good communication with their friends. It means that the students can get good communication with their friends and they can more courageous to tell their opinion to other friends

Based on the observation in the teaching and learning activity, when they create summary, the students have a good communication with their friend in their group. And when they read their summary in front of the class, they look courageous to tell their task in front of the class

This method can make classroom situation more alive because each group more focuses on their problem from the text.

Based on teacher's interview, it shows that in learning activity, the classroom can be alive when using this method. The teacher states that when using this method, the students look enthusiastic. It makes classroom look alive. It means that this method can make the learning activity more alive because all of students look enthusiastic. Based on student's interview, the student states that they can focus on the materials well, so it can make the learning activity be better. It means that the student focus when they get material from the teacher.

Based on observation, in the teaching and learning process, the students focus when the teacher gives explanation about the materials of narrative text. Furthermore, when they can pay attention and focus on the teacher's explanation. It can make the classroom situation more alive because the students are not crowded.

The disadvantages of cooperative script in teaching reading are explained as follows:

The classroom is crowded because many students are noisy when they tell their opinion in their group.

Based on the teacher's interview, the teacher states that the weakness of this method is many students are noisy in the class when they tell their opinion. It means that 
when the students tell their opinion to others. It makes the classroom become crowded and noisy. Based on student's interview, the student states that the classroom become crowded and noisy. It is same as teacher's statement that when using this method in the classroom, it can make learning activity crowded. Based on observation, it shows that in the classroom, all of the students tell their opinion louder so that it makes classroom crowded.

The teacher gives less attention to the students in every group.

Based on the teacher's interview, the teacher states that the teacher cannot give balanced attention for every group because the teacher only focuses on some group. It means that in teaching learning process, the teacher less monitored to the students. He can not give attention in every group. Based on students' interview, the student also states that the teacher cannot paid attention to their group because the teacher only focus on which some groups look enthusiastic. It means that the students have opinion that the teacher cannot give attention for each group because the teacher only focuses on some group.

Based on observation in the class, when the students work together in group, the researcher can see that teacher less monitored the students because he only focuses on some groups that seem really focus on their task. So, it makes other group look crowded.

\section{Conclusion}

The application of cooperative script in teaching reading of narrative text has three steps. In pre-activities, the teacher greets students, checks students' attendance list, and gives apperception to the students. In whilst-activities, the teacher explains narrative text. After that, the teacher asks students to make a group to make a summary based on text entitled "Snow White". Then, the teacher divides students as reader and listener. The reader reads their summary and listener listens it carefully to correct the summary from the reader. The teacher also helps the students to correct become a good summary. In post-activities, the teacher closes the learning activity.

Cooperative script method has many advantages for the students and teacher. Firstly, this method can make students enjoy the learning activities. Secondly, this method can motivate students to be better in reading activities especially understanding the materials. Thirdly, this method can help students to be more creative in arranging summary using their own words. They also can comprehend the materials well. Fourthly, it makes students more focus on their task. Fifthly, it can help students to be more communicative with their friends to tell their opinions. Sixth, this method makes students courageous to tell their opinion in front of the class. The last, this method can make classroom situation more alive because each group focuses on their problem from the text.

Meanwhile, the cooperative script method also has disadvantages in teaching reading. First, the classroom is crowded because many students are noisy when they tell their opinion in their group. Second, the teacher gives less attention in every group. Based on observation in the class, when the students work together in group, the researcher can see that teacher give less attention to the students because he just focusses on some groups that seem really serious on doing their task. So it makes other group look crowded.

The application of cooperative SCRIPT method in teaching ... (Brigitta Septarini Rahmasari) 


\section{References}

Agus, S. 2013. Cooperative Learning: Teori dan Aplikasi Paikem. Yogyakarta: Pustaka Pelajar.

Anderson, Mark. and Anderson, Kathy. 1997. Text Types In English. Australia: Macmillan.

Ball, Mieke. 2009. Narratology: Introduction to the Theory of Narrative. Second Edition.Toronto: University of Toronto Press.

Bambang Yudi Cahyono. 2011. Techniques and Strategies to Enhance English Language Learning. Malang: State University of Malang Press.

Dat Tran, Van. 2013. Theoretical Perspectives Underlying the Application of Cooperative Learning in Classrooms. International Journal of Higher Education.

Doty, Jane K., Cameron, Gregory N., and Barton, Mary Lee. 2003. Teaching Reading in Social Studies. Colorado: McREL.

Grabe, William and Stoller, Frederica L. 2002. Teaching and Researching Reading. Australia: Longman.

Johnson, D. W., \& Johnson, R.T. 2002. Cooperative learning methods: A meta-analysis. Journal of Research in Education.

Jolliffe, Wendy. 2007. Cooperative Learning in the Classroom. London: Paul Chapman.

Kagan, S. 2009. Cooperative Learning. CA: Kagan Cooperative Learning.

Kristiawan, Muhammad. 2013. The Implementation of cooperative learning in English class of favorite School of secondary high school 5 Batusangkar, West Sumatera. International Journal of Educational Administration and Policy Studies.

Lailatun Nashiroh. 2012. The Improving Students' Reading Ability Through Cooperative Script Method at the Eight Grade of SMP N 1 Jenangan Ponorogo in Academic Year 2012/2013. Ponorogo: Muhammadiyah University Ponorogo.

Nunan, David. 2003. Practical English Language Teaching. Sydney: The Mc. Graw Hill Company.

Slavin, Robert E. 1995. Cooperative Learning: Theory, Research and Practice. Second edition. Massachusetts: Allyn and Bacon.

2006. Educational Psychology: Theory and Practice. Eighth Edition. Boston: Allyn and Bacon.

2009. Edueational Psychology: Theory and Practice. Ninth Edition. New York: Pearson.

Lazarowitz, Rachel Hertz and Miller, Norman. 1995. Interaction in cooperative groups: The Theoretical Anatomy of Group Learning. USA: Cambridge University Press. 
Urquhart, A.H and Weir, C.J. 1998. Reading in a Second Language. London: Longman.

Yin, K. Robert. 2011. Qualitative Research from Start to Finish. New York: The Guildford Press. 